\title{
Organizational Flexibility, Employee Security, and Organizational Efficiency - a Case Study of Slovenian Public and Private Sector Organizations
}

\author{
Tatjana Kozjek1, Marko Ferjan² \\ ${ }^{1}$ University of Ljubljana, Faculty of Administration, Gosarjeva Street 5, 1000 Ljubljana, Slovenia, \\ tatjana.kozjek@fu.uni-lj.si \\ University of Maribor, Faculty of Organizational Sciences, Kidričeva Street 55a, 4000 Kranj, Slovenia, \\ marko.ferjan@fov.uni-mb.si
}

\begin{abstract}
Background: Literature defines different types of flexibility and security with regard to work. Regardless of which type of flexibility or security is discussed, the consequences for individuals, organizations or employers and society are significant.

Purpose: The purpose of the research was to compare and analyse the correlation between the different types of flexibility and security in work and organizational efficiency.

Methodology: Data was gathered using the Computer-Assisted Web Interview (CAWI) method. A link to an online questionnaire was e-mailed to randomly selected organisations across all economic sectors in Slovenia that had a published e-mail address, either in business directories or on a company website. We asked them to forward our e-mail to their employees. The correlation between different variables was used for data analysis.

Results: The results of our research show that there is a low positive level of correlation between different types of flexibility and security in the context of work and also between different types of flexibility in work and organizational efficiency. The correlation between different types of security in work and organizational efficiency is positive and medium strong.

Conclusion: It is recommended that the legislators be aware of the importance of their correlation with organizational efficiency when preparing legislative amendments regarding introduction of the flexibility and security in the field of work.
\end{abstract}

Keywords: flexibility, flexible employment contracts, employee income security, job security, reproductive skills security, organizational efficiency

\section{Introduction}

The relevant literature identifies different types of flexibility related to work in organizations: internal and external numerical flexibility, functional flexibility, wage and labour costs flexibility, as well as external and procedural flexibility. The problem of the organisational flexibility is also related to the problem of the employees' security. The literature identifies different types of security, which are related to work in organizations: economic, social or income security, representation security, employment, job, work and working ability security, and combination security. Regardless of which type of flexibility or security we discuss, the consequences are significant for individuals, organizations or employers and society.

The public sector is represented by all public entities as direct and indirect state budget users. Their activities are in the public interest, their founder or majority owner is the state or local community. The public sector consists of public authorities, administrations, local governments, 
public agencies, public funds, public institutions, public commercial institutions and other public entities that are established to provide public services (in the public interest), which are also indirect users of the state budget and the budget of local communities. The public sector executes decisions made about public affairs in the political sector (the National Assembly, the Municipal Council), the executive sector (the Government, the Mayor), and at operational and professional levels (public administration) and within public services (health, education, culture, social protection). The private sector is represented by organizations that do not belong to the public sector and are not related to the direct or indirect state budget or budgets of local community users.

The purpose of the research was to compare and analyse the correlation between different types of flexibility and security in work and organizational efficiency in public and private sector organizations. We want to determine whether there is a correlation between different types of flexibility and security in work and organizational efficiency. If such correlation exists, legislators should take it into account during the preparation of legislative changes.

The first part of the article presents various types of flexibility and security in work and organizational efficiency. The second part presents results of the comparison and analysis of the correlation between different types of flexibility and security in work and organizational efficiency in public and private sector organizations.

\section{Literature review}

\subsection{Job flexibility and security}

According to Jonsson (2007), flexibility, means that employers can 'hire and fire' workers at will due to weak labour-market regulations. The literature describes different types of flexibility in the context of work. Goodwin (2002) defines numerical flexibility as the capability of organizations and employers to adjust the number of employees to their needs. Altuzarra and Serrano (2010) define numerical flexibility as statistical flexibility and relate it to other job contracts. Tros and Wilthagen (2004), the ILO (2004) and Wachsen and Blind (2011) describe numerical flexibility as external and internal numerical flexibility. External flexibility is defined as ability of the organization to adjust number of employees to the business activities by using different types of employment, whether they reduce or increase the number of employees. Internal flexibility indicates the ability of the organization to adjust their work to their business needs by changing their work time. Acording to HerzogStein and Zapf (2014) internal-numerical flexibility refers to the internal adjustment of the amount of labour input used in an establishment's production process without recourse to the external labour market. This flexibility is achieved by using a variety of working-time arrangements. External-numerical flexibility defined as adjusting an establishment's use of labour through hiring and firing, temporary employment or fixed-term contracts.

According to Tros and Wilthagn (2004), and the ILO (2004), functional flexibility relates to an organization's adjustment of its work to its business needs by defining tasks and relocating employees to different job positions. Goodwin (2002), and Wachsen and Blind (2011) interpret functional flexibility as multi-functionality or capability to do other work besides one's own. Altuzarra and Serrano (2010) define that type of flexibility as dynamic flexibility. Eichhorst et al. (2010) make a distinction between external and internal functional flexibility. The external type includes qualified, trained, educated and competent individuals, who can adapt to structural changes. Internal functional flexibility is the ability of organizations to respond to changes in demand with a flexibly organized working process, requiring skilled, well-trained and competent employees, who can perform multiple tasks.

The economic aspect is analyzed in the context of wage flexibility and features the variable part of wage regarding job performance and overall business performance (Tros and Wilthagen, 2004; ILO, 2004; Wachsen and Blind, 2011). Eichhorst et al. (2010) associate that type of flexibility with adjustment of actual wages to macroeconomic circumstances. Vermeylen and Hurley (2007) define the externalization of flexibility, which refers to the possibility of employment and unemployment contracts (employment through employment agencies).

A long-term employment contract is a typical type of employment contract. Characteristically, no exact date of termination of the position specified on such a contact, and they are commonly believed to be more secure and stable than other types of job contracts. The literature (e. g. Soltwedl et al., 1999; ILO, 2004a; Pit Catouphes et al., 2009; Richman et al., 2010) defines different atypical or flexible types of employment contracts: shifting employees to other jobs at another location, limited-time working, tele-working, flexible working hours, half or part-time working, job-sharing, concentrated work week days (for example: four days of longer working time, with the fifth day off), hiring occasional employees.

The European Commission (2009) defines geographical flexibility (mobility) and further divides them into flexibility (mobility) within and outside the country as well as mobility within and between organizations.

According to Jonsson (2007), despite flexibility, stability means that employees have strong employment protection, perceived as job security. Literature describes different types of job security. The ILO (2004) defined the term 'economic security' as derived from basic social security. It is also related to the ability to access 
infrastructure for basic health needs, education, housing, information and other job-associated securities. Nesadurai (2005) separates economic security on micro and macro levels. Economic security on the micro level refers to the security of an employee's job and income. Economic security on the macro level is directed to ensuring the integrity of the market, creating growth, prosperity in a society that enables the well-being of the individual.

According to Standing (1999), the security of employee income indicates the actual and expected income that an individual earns with work or receives as social or other transfers. Security of employee income includes income level (absolutely and relatively), regarding payments, and expectations of current and future income, such as minimum wage, wage of indexation and progressive taxation. The ILO (2004) and Wilthagen et al. (2004) state that this form of security relates to an employee's opportunity to obtain basic resources and have a decent life.

Work security relates to the work conditions in organizations that encourage employee well-being. According to Standing (1999), this type of security is reflected in the regulations of health and security in the workplace, stress prevention, workplace bullying, discrimination, and absenteeism. The State Service Commission (2003) describes harassment (racial and sexual) and intimidation in the workplace. The ILO (2004) warned about the restrictions on working hours and night work.

The State Service Commission (2003) states that work security is also regarded as harassment (racial, sexual) and bullying in the workplace. The ILO (2004) in this context also mentions limits to working time and night work.

Security related to education, training and development are the skills that Standing (1999) defines as reproductive skills security. In his opinion, this type of security represents the ability of the individual to achieve such education and training that promotes opportunities for employment. The ILO (2004) defines it as employee skills security, which means the opportunities for the acquisition, retention, and the development of individual education, abilities, skills and knowledge.

According to Standing (1999), combination security represents the individual's ability to coordinate paid work with other responsibilities. Hobson (2014) defines this coordination as the work-life balance. Tros (2004) describes combination security as coordination between professional and private life, work-life balance and flexible, early (partial) retirement and flexible working time.

Muffels and Luijkx (2005) state that organizations that are able to compete on the labour market successfully are able to afford higher levels of social security, which is also a requirement for maintaining of high level flexibility. Green and Leeves (2013) conducted research to determine whether there is a link between unemployment, wages, job security, financial security and workers' wellbeing for workers in flexible employment. They found that workers in flexible employment encounter more unemployment and experience increased job insecurity; unemployment is associated with wage penalties. Lower wages, job insecurity and financial insecurity affect well-being. However, these adverse outcomes are mitigated by longer job tenure.

In connection with their results, in our research we wanted to determine whether a correlation between different types of flexibility and security in the field of work (present in the literature review) exists. Therefore, we posit Hypothesis $\mathrm{H} 1$ :

H1: The correlation between different types of flexibility and security in the field of work exists.

\subsection{Organizational efficiency}

According to Kovac (2007), organizational efficiency is a positive result of the comparison between the inputs and the results obtained. Mandl et al. (2008) and Sorber (1999) posit that efficiency is the relationship between inputs and effects; therefore, efficiency shows effects regardless of the inputs or resources needed to achieve the objectives. Robbins and Coulter (2005) state that efficiency means obtaining the greatest possible output out of the smallest quantities of inputs.

The relevant literature describes different methods of the measurement of organizational efficiency. Mandl et al. (2008) write that the efficiency cannot be measured directly; therefore, different approaches to data and methodological framework are used. According to Koh and Saad (2007), benchmarking or comparative analysis are frequently used methods. Rolstadas (1995) posits a systematic, iterative process of evaluation and selection the leading organizations in the industry.

For the efficiency measurement, there is no one single method. The Common Assessment Framework (CAF) is one benchmarking method; it is a total quality management tool developed by the public sector for the public sector, inspired by the Excellence Model of the European Foundation for Quality Management (EFQM $®$ ). It is based on the premise that excellent results in organisational performance, citizens/customers, people, and society are achieved through leadership driving strategy and planning, people, partnerships, resources, and processes. It looks at the organisation from different angles simultaneously (EIPA, 2013). Aristovnik et al. (2012) write that the CAF is easy to use and takes into account the particularities of the public sector (the impact of the policy, professional work, customer orientation, non-financial results). The authors emphasize that the optimal effects of the assessment are achieved if a self-assessment principle is used, because 'the employees knew the organization the best', but a credible outcome requires a critical review. 
In connection with employee efficiency, Abdolreza et al. (2013) studied wage flexibility. They determined that wage and salary factors have a great effect on efficiency. Wright and Davis (2003) determined that higher security of employment has an impact on lower motivation for work and lower productivity. In their research, Dessler (1993), Guest (2004), Egger-Peitler et al. (2007), Wanyama and Mutsotso (2010), Talebi et al. (2012), determined that security of employment has a positive impact on independency, motivation, productivity of the employees and increase their loyalty to the organization. Salaries, employment security, security and health at work, possibilities regarding education and promotion also have an impact on organizational efficiency. Baptiste (2008) and the Regus Global Report (2011) write that easier harmonization of professional and family (private) lives leads to lower levels of employee absence, their greater precision, higher productivity and loyalty to the organization. In their research, Helpern (2005), Kossek (2005), Rowlattova et al. (2006), Davis and Kalleberg (2006), Kelly et al. (2008), Kossek and Hammer (2008), Kossek and Michel (2010) and the Regus Global Report (2011) studied flexibility in relation to the organizational efficiency and ascertained that the correlation exists. Flexibility has a positive effect on the organizational efficiency, because employees are motivated, productive, which consequently leads to better products and services quality, larger commitment to the organization and lower costs.

In connection to these results, in our research we wanted to determine whether different types of flexibility and security in the context of work correlate with organizational efficiency in public and private sector organizations. Therefore, we posited two more research hypotheses:

H2: A correlation between different types of security in the context of work and organizational efficiency exists.

H3: A correlation between different types of flexibility in the context of work and organizational efficiency exists.

In our research, we used Robbins and Coulter's (2005) definition of organizational efficiency, which means obtaining the greatest possible output from the smallest quantities of inputs.

\section{Methodology}

The purpose of the research was to compare and analyse correlations between the different types of flexibility and security in the context of work and organizational efficiency in public and private sector organizations. The research was conducted in Slovenia from September 2011 to October 2011. Data was gathered using the ComputerAssisted Web Interview (CAWI) method. A link to an online questionnaire was e-mailed to 6,000 randomly selected organisations in all the sectors of the economy in Slovenia that had a published e-mail address, either in business directories or on a company website.

The link to the online questionnaire was sent by e-mail to official e-mail addresses, asking them to forward it to employees. We do not know whether this was done, which could imply that the survey did not include manual workers, industry workers but mainly workers in administration, or that questionnaire fulfilled one or many employees from the same organization.

The reason for the low responsiveness rate was that the survey was carried out online. Other reasons that employee state were:

- at the time of our research, they had a number of other research projected in which they participated,

- the leader decided that employees would not be allowed to participate in the research,

- $\quad$ they did not have time.

Conclusions are therefore limited only to the part of population that has been included in the sample. The research was carried out at the time of the economic crisis, which also affects the results of this research.

\subsection{Instrument}

The questionnaire was divided into two parts. The first was about demographic details. The study gathered data about the organization and people who participated on the research:

- the type of the organization,

- the activity in the private sector organizations and the number of the employees,

- employment, workplace, gender, age and education.

The second part of the questionnaire gathered information about the flexibility of organizations, employees' security and organizational efficiency. Table 1 shows descriptions of the flexibility, security and efficiency variables.

Our research included a comparison of the organizational efficiency in public and private sector organizations. For the efficiency measurement, there is not just one single method; according to Aristovnik (2012), the optimal effects of the assessment are achieved if a self-assessment principle is used, because 'the employees knew the organization the best'; therefore, in our research the employees evaluated the organizational efficiency. The results, therefore, show the evaluated and not actual organizational efficiency. We decided to take this approach, because we wanted to obtain information about the organizational efficiency, while ensuring the anonymity of the participants of the research. 
Questions related to organizational efficiency in our research were, therefore, taken from the results criteria from the CAF. The questions included in the questionnaire analyze the quality aspects of the services or products, the accuracy and productivity of employees, the information transparency and cost-effectiveness of organizations, short-term objectives, and stakeholder satisfaction. Positive results of these variables show organizational evaluated efficiency.

Table 1: Descriptions of the flexibility, security and efficiency variables. Source: own

\begin{tabular}{|c|c|}
\hline \multicolumn{2}{|r|}{ Variables of the flexibility } \\
\hline \multicolumn{2}{|c|}{ Variables of numerical flexibility } \\
\hline FA & The capability of an organization to adjust the number of employees to the need of organizations. \\
\hline FB & $\begin{array}{l}\text { The capability of an organization to adjust the work of organizational and/or business needs by using differ- } \\
\text { ent forms of employment. }\end{array}$ \\
\hline $\mathrm{FC}$ & $\begin{array}{l}\text { The capability of an organization to adjust the work of organizational and/or business needs through over- } \\
\text { time work. }\end{array}$ \\
\hline FD & $\begin{array}{l}\text { The capability of an organization to adjust the work of organizational and/or business needs by using copy- } \\
\text { rights or similar job contracts, e.g. service contracts. }\end{array}$ \\
\hline FE & $\begin{array}{l}\text { The capability of an organization to adjust the work of organizational and/or business needs by hiring stu- } \\
\text { dents. }\end{array}$ \\
\hline $\mathrm{FF}$ & $\begin{array}{l}\text { The capability of an organization to adjust the work of organizational and/or business by reducing the num- } \\
\text { ber of employees. }\end{array}$ \\
\hline FG & $\begin{array}{l}\text { The capability of an organization to adjust the work of organizational and/or business by increasing the } \\
\text { number of employees. }\end{array}$ \\
\hline $\mathrm{FH}$ & $\begin{array}{l}\text { The capability of an organization to adjust the work of organizational and/or business by changing the vol- } \\
\text { ume of working hours. }\end{array}$ \\
\hline FI & $\begin{array}{l}\text { The capability of an organization to adjust the work of organizational and/or business by timing of work or } \\
\text { by changing working time. }\end{array}$ \\
\hline \multicolumn{2}{|r|}{ Variables of functional flexibility } \\
\hline FJ & $\begin{array}{l}\text { The capability of an organization to adjust the content of work of an individual to organizational and /or } \\
\text { business needs in the context of the definition of working assignments by changing systematization. }\end{array}$ \\
\hline FK & $\begin{array}{l}\text { The capability of an organization to adjust the content of work of an individual to organizational and /or } \\
\text { business needs in the context of the definition of working assignments by organizational instructions. }\end{array}$ \\
\hline FL & $\begin{array}{l}\text { The capability of an organization to adjust the content of work of an individual to organizational and /or } \\
\text { business needs by relocating employees to different job positions without changing employment contracts. }\end{array}$ \\
\hline FM & $\begin{array}{l}\text { The capability of organization to adjust the content of work of an individual to organizational and /or busi- } \\
\text { ness needs by relocating employees to different job positions with termination of an old and the offer of a } \\
\text { new employment contract. }\end{array}$ \\
\hline \multicolumn{2}{|c|}{ Variable of wage flexibility } \\
\hline FN & $\begin{array}{l}\text { The ability of the organizations to adjust wages according to the job performance of an individual employ- } \\
\text { ee. }\end{array}$ \\
\hline $\mathrm{FO}$ & The ability of the organizations to adjust wages according to business results and business performance. \\
\hline \multicolumn{2}{|c|}{ Variable of location flexibility } \\
\hline $\mathrm{FP}$ & The ability of the organization to transfer employees to other job positions or to other locations. \\
\hline \multicolumn{2}{|c|}{ Variable of flexible employment contracts } \\
\hline $\mathrm{FQ}$ & $\begin{array}{l}\text { The ability to create flexible employment contracts that would meet the needs of the organization with } \\
\text { tele-working from home, within domestic country. }\end{array}$ \\
\hline
\end{tabular}


Table 1 (continued)

\begin{tabular}{|c|c|}
\hline FR & $\begin{array}{l}\text { The ability to create flexible employment contracts that would meet the needs of the organization with } \\
\text { tele-working from abroad. }\end{array}$ \\
\hline FS & $\begin{array}{l}\text { The ability to create flexible employment contracts that would meet the needs of the organization with limit- } \\
\text { ed-time working. }\end{array}$ \\
\hline FT & $\begin{array}{l}\text { The ability to create flexible employment contracts that would meet the needs of the organization with flexi- } \\
\text { ble working hours. }\end{array}$ \\
\hline FU & $\begin{array}{l}\text { The ability to create flexible employment contracts that would meet the needs of the organization with half } \\
\text { or part-time working. }\end{array}$ \\
\hline FV & $\begin{array}{l}\text { The ability to create flexible employment contracts that would meet the needs of the organization with } \\
\text { job-sharing. }\end{array}$ \\
\hline FW & $\begin{array}{l}\text { The ability to create flexible employment contracts that would meet the needs of the organization with con- } \\
\text { centrated works week days, for example: four days of longer working time, with the fifth day off). }\end{array}$ \\
\hline FX & $\begin{array}{l}\text { The ability to create flexible employment contracts that would meet the needs of the organization by hiring } \\
\text { employees from an employment agency. }\end{array}$ \\
\hline FY & $\begin{array}{l}\text { The ability to create flexible employment contracts that would meet the needs of the organization by hiring } \\
\text { occasional employees. }\end{array}$ \\
\hline FZ & $\begin{array}{l}\text { The ability to create flexible employment contracts that would meet the needs of the organization by hiring } \\
\text { students. }\end{array}$ \\
\hline \multicolumn{2}{|r|}{ Variables of the security } \\
\hline \multicolumn{2}{|c|}{ Variables of economic security } \\
\hline SA & The possibilities of an individual to access infrastructure for basic health needs (in general). \\
\hline SB & The possibilities of an individual to access infrastructure for the basic health needs of safety at workplace. \\
\hline $\mathrm{SC}$ & The possibilities of an individual to access infrastructure for the basic needs of education (in general). \\
\hline SD & $\begin{array}{l}\text { The possibilities of an individual to access the basic needs of education at workplace upon request of the } \\
\text { employee and at the employer's expense. }\end{array}$ \\
\hline SE & The possibilities of an individual to access workplace training based on the needs of employers. \\
\hline SF & The possibilities of an individual to buy a house. \\
\hline SG & The possibilities of an individual to rent an apartment. \\
\hline SH & An individual's level of job security. \\
\hline \multicolumn{2}{|c|}{ Variables of income security } \\
\hline SI & $\begin{array}{l}\text { The possibilities of an individual to have resources for a decent life (such as income, the regulation of mini- } \\
\text { mum wage). }\end{array}$ \\
\hline SJ & The possibilities of an individual to have opportunities for wages coordination and indexation. \\
\hline \multicolumn{2}{|c|}{ Variable of workplace (service) security } \\
\hline SK & The level of protection of an individual from large changes in working conditions by the current employer. \\
\hline \multicolumn{2}{|c|}{ Variable of work security } \\
\hline SL & $\begin{array}{l}\text { The possibilities of an individual to have safe working conditions that also enable well-being in the work- } \\
\text { place. }\end{array}$ \\
\hline \multicolumn{2}{|c|}{ Variable of employee job skills security } \\
\hline SM & $\begin{array}{l}\text { The possibilities of an individual to achieve education and training, as well as the opportunities to improve } \\
\text { skills and competences acquisition, retention and development. }\end{array}$ \\
\hline \multicolumn{2}{|c|}{ Variables of combination security } \\
\hline $\mathrm{SN}$ & The possibilities of an individual to have work-life balance, enabling an individual to satisfy family needs. \\
\hline SO & $\begin{array}{l}\text { The possibilities of an individual to have work-life balance, enabling an individual to satisfy the needs to } \\
\text { integrate into civil, political, religious and other organizations. }\end{array}$ \\
\hline
\end{tabular}


Table 1 (continued)

\begin{tabular}{|l|l|}
\hline \multicolumn{2}{|l|}{ Variables of the efficiency } \\
\hline EA & The organization service compliance with the quality standards and quality of service provision. \\
\hline EB & The accuracy of the employees in terms of the compliance with the deadlines. \\
\hline EC & The accuracy of the employees in terms of the respect for the services content. \\
\hline ED & Information transparency of the employees. \\
\hline EE & Information transparency of the customer. \\
\hline EF & Employee productivity (percentage of the working time required to finish the task). \\
\hline EG & $\begin{array}{l}\text { Organizational cost-efficiency (whether the services or products are obtained / performed with optimal } \\
\text { costs). }\end{array}$ \\
\hline EH & Achieving short-term (operational) goals with the respect to the scope of services. \\
\hline EI & Achieving short-term (operational) goals depending on the quality services. \\
\hline EJ & Stakeholders' satisfaction (e.g. citizens, other organizations). \\
\hline
\end{tabular}

Employees who participated in the research evaluated the variables of flexibility, security and efficiency numerically from the lowest (1) to the highest (7) mark. Table 2 shows the measurement scale. The reliability test showed that the data gathered about organizational flexibility was suitable for analysis because the Cronbach's Alpha coefficient was 0.916 .
The reliability test showed that the data gathered about job security was suitable for analysis because the Cronbach's Alpha coefficient was 0.887 .

The reliability test showed that the data gathered about organizational efficiency was suitable for analysis because the Cronbach's Alpha coefficient was 0.952.

Table 2: A measurement scale. Source: own

\begin{tabular}{|l|l|l|l|}
\hline Mark & Variables of flexibility & Variables of security & Variables of efficiency \\
\hline 1 & very inflexible & $\begin{array}{l}\text { an individual does not have } \\
\text { (quoted) opportunities }\end{array}$ & $\begin{array}{l}\text { very ineffective/inconsistent/ } \\
\text { unproductive/unsatisfied }\end{array}$ \\
\hline 3 & inflexible & $\begin{array}{l}\text { an individual has very poor } \\
\text { (quoted) opportunities }\end{array}$ & $\begin{array}{l}\text { ineffective/inconsistent /unproductive/ } \\
\text { unsatisfied }\end{array}$ \\
\hline 4 & partly inflexible & $\begin{array}{l}\text { an individual has bad (quoted) } \\
\text { opportunities }\end{array}$ & $\begin{array}{l}\text { partly ineffective/inconsistent/ } \\
\text { unproductive/unsatisfied }\end{array}$ \\
\hline 5 & neither is, nor is flexible & $\begin{array}{l}\text { an individual has limited (quoted) } \\
\text { opportunities }\end{array}$ & $\begin{array}{l}\text { neither is, nor is effective/consistent/ } \\
\text { productive/satisfied }\end{array}$ \\
\hline 6 & partly flexible & $\begin{array}{l}\text { an individual has good (quoted) } \\
\text { opportunities }\end{array}$ & $\begin{array}{l}\text { partly effective/ consistent/productive/ } \\
\text { satisfied }\end{array}$ \\
\hline 7 & flexible & $\begin{array}{l}\text { an individual has very good } \\
\text { (quoted) opportunities }\end{array}$ & effective/consistent /productive/satisfied \\
\hline
\end{tabular}

\subsection{Sample}

The questionnaire was returned by 1,009 employees in organizations in the private and the public sectors. The participants are broken down as follows: $25.5 \%$ were employed in the private sector and $74.5 \%$ in the public sector. $3.8 \%$ in government services, $12.9 \%$ in ministries,
$0.7 \%$ in directorates, $2.0 \%$ in tax administration, $4.0 \%$ in social work centres, $4.6 \%$ in inspectorates, $17.8 \%$ in administrative units, $14.2 \%$ in municipalities and $5.1 \%$ in public institutions and public agencies. Gender and age are broken down as follows: $70.3 \%$ participants were women and $29.7 \%$ were men. The participant's average age was 42.6 years. Education among participants is as 
Table 3: Average estimates and standard deviations of the flexibility, security and efficiency variables for the participants, employed in private and public sector organizations. Source: own

\begin{tabular}{|c|c|c|c|c|}
\hline \multirow{2}{*}{ Variable } & \multicolumn{3}{|c|}{ Mean } & \multirow{2}{*}{ Std. Deviation } \\
\hline & Private sector & Public sector & Total & \\
\hline FA & 3.88 & 3.67 & 3.73 & 1.621 \\
\hline FB & 3.79 & 3.31 & 3.44 & 1.755 \\
\hline $\mathrm{FC}$ & 4.72 & 3.43 & 3.77 & 1.912 \\
\hline FD & 2.78 & 2.86 & 2.84 & 1.829 \\
\hline $\mathrm{FE}$ & 3.81 & 3.17 & 3.34 & 1.896 \\
\hline FF & 2.69 & 3.10 & 2.99 & 1.834 \\
\hline FG & 3.06 & 2.72 & 2.81 & 1.693 \\
\hline FH & 4.60 & 3.07 & 3.49 & 1.928 \\
\hline FI & 5.30 & 3.40 & 3.91 & 1.990 \\
\hline FJ & 2.99 & 3.73 & 3.53 & 1.822 \\
\hline FK & 4.91 & 4.14 & 4.35 & 1.647 \\
\hline FL & 4.06 & 3.53 & 3.67 & 1.825 \\
\hline FM & 2.45 & 2.71 & 2.64 & 1.694 \\
\hline $\mathrm{FN}$ & 2.68 & 2.16 & 2.30 & 1.651 \\
\hline $\mathrm{FO}$ & 2.96 & 2.09 & 2.33 & 1.639 \\
\hline FP & 4.21 & 2.87 & 3.24 & 1.865 \\
\hline FQ & 2.79 & 1.97 & 2.20 & 1.751 \\
\hline FR & 2.07 & 1.73 & 1.83 & 1.498 \\
\hline FS & 4.57 & 3.15 & 3.54 & 1.872 \\
\hline FT & 5.01 & 2.92 & 3.50 & 1.984 \\
\hline $\mathrm{FU}$ & 3.80 & 2.83 & 3.10 & 1.837 \\
\hline FV & 3.10 & 2.53 & 2.69 & 1.744 \\
\hline FW & 2.88 & 1.87 & 2.15 & 1.673 \\
\hline FX & 1.92 & 1.68 & 1.75 & 1.362 \\
\hline FY & 1.88 & 1.74 & 1.78 & 1.374 \\
\hline $\mathrm{FZ}$ & 3.75 & 3.04 & 3.24 & 1.873 \\
\hline SA & 5.67 & 4.80 & 5.04 & 1.558 \\
\hline SB & 5.65 & 4.82 & 5.05 & 1.520 \\
\hline $\mathrm{SC}$ & 5.48 & 4.50 & 4.78 & 1.625 \\
\hline SD & 2.62 & 3.64 & 3.35 & 1.866 \\
\hline SE & 3.60 & 4.47 & 4.23 & 1.816 \\
\hline SF & 1.80 & 1.92 & 1.89 & 1.270 \\
\hline SG & 2.53 & 2.56 & 2.55 & 1.608 \\
\hline $\mathrm{SH}$ & 4.22 & 4.38 & 4.33 & 1.715 \\
\hline SI & 4.00 & 4.04 & 4.03 & 1.584 \\
\hline SJ & 3.14 & 2.44 & 2.64 & 1.503 \\
\hline SK & 4.55 & 4.02 & 4.17 & 1.649 \\
\hline SL & 5.61 & 4.77 & 5.00 & 1.555 \\
\hline SM & 5.55 & 4.45 & 4.75 & 1.578 \\
\hline
\end{tabular}


Table 3 (continued)

\begin{tabular}{|l|r|r|r|r|}
\hline SN & 4.52 & 4.49 & 4.50 & 1.567 \\
\hline SO & 5.29 & 4.36 & 4.62 & 1.705 \\
\hline EA & 6.00 & 4.85 & 5.18 & 1.462 \\
\hline EB & 5.76 & 4.98 & 5.19 & 1.524 \\
\hline EC & 6.10 & 5.11 & 5.38 & 1.466 \\
\hline ED & 5.48 & 4.58 & 4.83 & 1.603 \\
\hline EE & 5.86 & 4.69 & 5.02 & 1.581 \\
\hline EF & 5.58 & 4.82 & 5.03 & 1.298 \\
\hline EG & 5.10 & 4.56 & 4.71 & 1.442 \\
\hline EH & 5.51 & 4.87 & 5.05 & 1.385 \\
\hline EI & 5.93 & 4.83 & 5.14 & 1.471 \\
\hline EJ & 5.75 & 4.75 & 5.03 & 1.413 \\
\hline
\end{tabular}

Table 4: Average estimates and standard deviations of the values of the flexibility, security and efficiency variables for the participants, employed on managerial and non-managerial workplace. Source: own

\begin{tabular}{|c|c|c|c|c|}
\hline \multirow[t]{2}{*}{ Variable } & \multicolumn{3}{|c|}{ Mean } & \multirow[t]{2}{*}{ Std. Deviation } \\
\hline & $\begin{array}{l}\text { Managerial work- } \\
\text { place }\end{array}$ & $\begin{array}{l}\text { Non-managerial } \\
\text { workplace }\end{array}$ & Total & \\
\hline FA & 3.90 & 3.67 & 3.73 & 1.620 \\
\hline FB & 3.38 & 3.46 & 3.44 & 1.754 \\
\hline $\mathrm{FC}$ & 3.82 & 3.74 & 3.76 & 1.915 \\
\hline FD & 2.72 & 2.88 & 2.84 & 1.827 \\
\hline $\mathrm{FE}$ & 3.37 & 3.34 & 3.35 & 1.901 \\
\hline $\mathrm{FF}$ & 2.97 & 2.99 & 2.99 & 1.833 \\
\hline FG & 2.68 & 2.85 & 2.81 & 1.690 \\
\hline $\mathrm{FH}$ & 3.60 & 3.46 & 3.49 & 1.929 \\
\hline FI & 4.05 & 3.87 & 3.91 & 1.994 \\
\hline FJ & 4.00 & 3.36 & 3.52 & 1.823 \\
\hline FK & 3.83 & 4.19 & 4.35 & 1.652 \\
\hline FL & 3.83 & 3.62 & 3.67 & 1.824 \\
\hline FM & 2.64 & 2.63 & 2.63 & 1.693 \\
\hline FN & 2.62 & 2.19 & 2.30 & 1.650 \\
\hline FO & 2.60 & 2.24 & 2.33 & 1.638 \\
\hline FP & 3.12 & 3.27 & 3.23 & 1.865 \\
\hline FQ & 2.09 & 2.22 & 2.19 & 1.748 \\
\hline FR & 1.75 & 1.84 & 1.82 & 1.493 \\
\hline $\mathrm{FS}$ & 3.40 & 3.60 & 3.55 & 1.872 \\
\hline FT & 3.53 & 3.49 & 3.50 & 1.982 \\
\hline FU & 3.03 & 3.12 & 3.10 & 1.838 \\
\hline $\mathrm{FV}$ & 2.76 & 2.66 & 2.69 & 1.742 \\
\hline FW & 2.12 & 2.15 & 2.14 & 1.668 \\
\hline FX & 1.63 & 1.78 & 1.74 & 1.356 \\
\hline
\end{tabular}


Table 4 (continued)

\begin{tabular}{|c|c|c|c|c|}
\hline $\mathrm{FY}$ & 1.77 & 1.77 & 1.77 & 1.367 \\
\hline $\mathrm{FZ}$ & 3.21 & 3.24 & 3.23 & 1.874 \\
\hline SA & 5.27 & 4.97 & 5.04 & 1.558 \\
\hline SB & 5.42 & 4.93 & 5.05 & 1.522 \\
\hline $\mathrm{SC}$ & 4.89 & 4.74 & 4.78 & 1.625 \\
\hline SD & 3.72 & 3.21 & 3.34 & 1.864 \\
\hline $\mathrm{SE}$ & 4.80 & 4.03 & 4.22 & 1.819 \\
\hline $\mathrm{SF}$ & 2.01 & 1.84 & 1.88 & 1.266 \\
\hline SG & 2.61 & 2.53 & 2.55 & 1.604 \\
\hline $\mathrm{SH}$ & 4.67 & 4.21 & 4.32 & 1.716 \\
\hline SI & 4.53 & 3.86 & 4.03 & 1.580 \\
\hline SJ & 2.95 & 2.53 & 2.64 & 1.499 \\
\hline SK & 4.65 & 4.00 & 4.17 & 1.647 \\
\hline $\mathrm{SL}$ & 5.46 & 4.84 & 5.00 & 1.561 \\
\hline SM & 5.18 & 4.61 & 4.75 & 1.578 \\
\hline SN & 5.09 & 4.29 & 4.49 & 1.569 \\
\hline SO & 5.01 & 4.48 & 4.61 & 1.708 \\
\hline EA & 5.46 & 5.09 & 5.18 & 1.462 \\
\hline EB & 5.38 & 5.13 & 5.19 & 1.525 \\
\hline EC & 5.59 & 5.31 & 5.38 & 1.466 \\
\hline ED & 5.31 & 4.66 & 4.82 & 1.606 \\
\hline EE & 5.45 & 4.86 & 5.01 & 1.582 \\
\hline $\mathrm{EF}$ & 5.12 & 5.00 & 5.03 & 1.298 \\
\hline EG & 4.94 & 4.63 & 4.71 & 1.443 \\
\hline $\mathrm{EH}$ & 5.28 & 4.97 & 5.05 & 1.386 \\
\hline EI & 5.39 & 5.06 & 5.14 & 1.472 \\
\hline EJ & 5.31 & 4.93 & 5.03 & 1.413 \\
\hline
\end{tabular}

follows: $8.1 \%$ of participants finished primary, vocational professional or middle professional education, $16.9 \%$ finished either a four-year high school or high school education, $29.0 \%$ finished college or higher education, $31.7 \%$ had university degree, $14.3 \%$ had finished postgraduate studies such as specialization, master's or doctoral degrees.

The types of contracts participants held were as follows: $85.0 \%$ of participants had permanent jobs, $11.9 \%$ had contract jobs, $1.0 \%$ were students, $1.3 \%$ had copyright, or service contracts, and $0.8 \%$ marked other choice, were retired, had a five-year mandate, were unemployed, selfemployed or officials.

\section{Results}

Table 3 shows average estimates and standard deviations of the flexibility, security and efficiency variables for the participants, employed in public and private sector organizations. The descriptions of these variables are shown in the Table 1.

Regarding the flexibility variables, the results of the research show that employees in the private sector evaluated most flexibility variables better than employees in the public sector. Employees in the private sector evaluated the following variables better:

- time adjustment to work,

- flexibility regarding working hours,

- flexibility regarding extension of working hours,

- the possibility of reallocating to different job positions, without changing their employment contract.

The results show that participants from the private sector 
have better possibilities of experiencing numerical and functional flexibility and mobility. Participants from the public sector evaluated the possibilities for tele-working worse than those from the private sector. Changes regarding increasing flexibility that would enable tele-working need to be performed by changing labour legislation.

Participants from the private and public sectors both agree that organizations do not hire employees through employment agencies very often. The reason might be the lack of trust or previous bad experience on the part of some individuals. We can avoid such problems by supervising these employment agencies. In general, participants from the public sector evaluated the situation in the field of work flexibility as low.

The results of our research show that participants evaluated security in the area of infrastructure for basic healthcare the highest. That is understandable because the labour law in Slovenia determines that the employer has to register the worker with the social insurance system and with the unemployment insurance system.

The possibilities of an individual to buy or rent an apartment or house are evaluated as the lowest, which might be a consequence of the current situation at the labour market, which is a result of the recent economic recession and the fact that, during this period, unemployment has risen only among the employees in the private sector. The state has to do more in the field of housing market, in order to increase the possibilities of individuals to buy or rent an apartment or house.

Participants from private sector organizations evaluated most of the values of variables of security and efficiency higher than participants from the public sector. The economic recession, as well as the planned reduction of employment in the public sector, had a large impact on the result.

Table 4 shows average estimates and standard deviations of the values of the flexibility, security and efficiency variables for the participants employed in managerial and non-managerial workplaces. The descriptions of these variables are shown in Table 1.

The results of the research show that participants employed on managerial workplaces evaluated highly:

- the capability of organization to adjust the content of work of an individual to organizational and /or business needs in the context of the definition of working assignments via changing systematization,

- the ability of the organizations to adjust wages according to business results and business performance,

- the capability of organization to adjust the content of work of an individual to organizational and / or business needs in the context of the definition of working assignments via organizational instructions.

The results, therefore, show that participants employed on managerial workplaces are enabled functional flexibility, more often than those on non-managerial workplaces, which is often also associated with better opportunities for participating in education and training, which also affects to better payment.

Regarding security, participants on managerial workplaces evaluated more highly:

- the possibilities of an individual to access infrastructure for the basic health needs of safety at workplace,

- the possibilities of an individual to access the basic needs of education at workplace upon request of the employee and at the employer's expense,

- the possibilities of an individual to access workplace training based on the needs of employers,

- the level of protection of an individual from large changes in working conditions by the current employer, the possibilities of an individual to have safe working conditions, which also enable well-being in the workplace, the possibilities of an individual to have work-life balance, understanding enabling an individual to satisfy family needs,

- the possibilities of an individual to have resources for a decent life (such as income, the regulation of minimum wage),

- the possibilities of an individual to have opportunities for wages coordination and indexation.

The results of the research show that participants, employed on managerial workplaces have better opportunities in regarding economic security, workplace security, job skills security and combination security. The fact that participants employed on managerial workplaces have better opportunities for education and work-life balancing is worrying. Organizations need to pay more attention to education. Employees, employed on managerial workplaces and those on non-managerial workplaces should have the same opportunities.

The results show that participants employed on managerial workplaces evaluated these variables related to the organizational efficiency on a higher position:

- the organization service compliance with the quality standards and quality of service provision,

- information transparency for the employees,

- information transparency for the customer,

- $\quad$ stakeholder satisfaction.

The results for the variables of organizational efficiency show that participants employed on both managerial positions and in non-managerial workplaces evaluated these variables as being good. The process of information for the participants employed on the non-managerial workplaces should be more transparent. The results show 
that participants employed on non-managerial workplaces evaluated quality standards and quality of service provision and stakeholder's satisfaction as worse, which might be because they evaluated these variables more rigorously.

Due to the large number of the variables, the analysis of the correlation was made according to content sections of the flexibility, security and efficiency variables. The values of the content sections of the variables were calculated as the arithmetic mean of the basic variables. Groups of flexibility and security variables are groups of independent variables, groups of organizational efficiency variables are groups of dependent variables.

Table 5 shows the symbols of the content sections of the flexibility, security and efficiency variables, that we researched.

Table 6 shows Pearson's correlation coefficients between the flexibility, security and efficiency variables. Analyses of the correlations show that there are in general weak, positive relations between variables of the flexibility and security in the context of work and between variables of the flexibility in the context of work and organizational efficiency (see Table 6).

Table 5: Symbols of the content sections of the flexibility, security and efficiency variables Source: own

\begin{tabular}{|c|c|}
\hline \multicolumn{2}{|r|}{ Content sections of the flexibility, security and efficiency variables } \\
\hline \multicolumn{2}{|r|}{ Content sections of the flexibility variables } \\
\hline F1 & The ability of the organization to adjust the level and /or number of employees to their needs. \\
\hline $\mathrm{F} 2$ & $\begin{array}{l}\text { The ability of the organization to adjust the work of organizational and/or business needs by using } \\
\text { different forms of employment, through overtime work, by using copyrights or similar job contracts } \\
\text { and/or service contracts, by hiring students, by reducing the number of employees, by increasing the } \\
\text { number of employees. }\end{array}$ \\
\hline F3 & $\begin{array}{l}\text { The ability of the organization to adjust the work of organizational and/or business needs by changing } \\
\text { the volume of working hours or by timing of work or by changing working time. }\end{array}$ \\
\hline F4 & $\begin{array}{l}\text { The ability of the organization to adjust the content of work of an individual to organizational and /or } \\
\text { business needs in the context of the definition of working assignments by changing job descriptions, } \\
\text { in the context of the definition of working assignments by organizational instructions, by relocating } \\
\text { employees to different job positions without changing employment contracts, by relocating employ- } \\
\text { ees to different job positions with termination of an old and offer of a new employment contract. }\end{array}$ \\
\hline F5 & $\begin{array}{l}\text { The ability of the organization to adjust wages according to the job performance of an individual em- } \\
\text { ployee or by business results and business performance. }\end{array}$ \\
\hline F6 & The ability of the organization to transfer employees to other job positions or to other locations. \\
\hline F7 & $\begin{array}{l}\text { The ability of the organization to create flexible employment contracts that would meet the needs } \\
\text { of the organization with tele-working from home, within the domestic country, tele-working from } \\
\text { abroad, contract jobs, flexible working hours, half or part-time working, job-sharing, concentrated } \\
\text { work week days (e.g. four days of longer working time, with the fifth day off), hiring employees from } \\
\text { employment agency, hiring occasional employees, hiring students. }\end{array}$ \\
\hline \multicolumn{2}{|r|}{ Content sections of the security variables } \\
\hline $\mathrm{S} 1$ & $\begin{array}{l}\text { Possibilities of an individual to access infrastructure for basic health needs in general, health and se- } \\
\text { curity needs at the workplace, education in general, education at the workplace upon request of em- } \\
\text { ployee and at the employer's expense, training in the workplace, buying a house, renting an apartment } \\
\text { and job security. }\end{array}$ \\
\hline $\mathrm{S} 2$ & $\begin{array}{l}\text { Possibilities of an individual to receive or have resources for a decent life (such as the regulation of } \\
\text { minimum wage), opportunities for wages coordination and indexation. }\end{array}$ \\
\hline S3 & $\begin{array}{l}\text { The level of an individual's protection from major changes in working conditions by the current em- } \\
\text { ployer. }\end{array}$ \\
\hline S4 & Possibilities of an individual to have safe working conditions and enable well-being. \\
\hline S5 & $\begin{array}{l}\text { Possibilities of an individual to achieve education and training, as well as opportunities for skills and } \\
\text { competences acquisition, retention and development. }\end{array}$ \\
\hline S6 & $\begin{array}{l}\text { Possibilities of an individual to have work-life balance, understanding of an individual for the needs } \\
\text { to integrate into civil, political, religious and other organizations. }\end{array}$ \\
\hline
\end{tabular}


Table 5 (continued)

\begin{tabular}{|c|l|}
\hline \multicolumn{2}{|c|}{ Content sections of the efficiency variables } \\
\hline E1 & Services or products consonance with quality standards or quality of ensuring services. \\
\hline E2 & Employees' precision in terms of adherence to deadlines or in terms of services content. \\
\hline E3 & $\begin{array}{l}\text { The transparency of the internal information for the service providers and the transparency of the } \\
\text { relevant information for the subscriber or recipient of the services. }\end{array}$ \\
\hline E4 & Employee's accuracy and productivity (percentage of working time needed to finish the work). \\
\hline E5 & Organizational cost-efficiency (are the services or products made with the optimal costs). \\
\hline E6 & $\begin{array}{l}\text { Achieving short-term (operative) goals, depending on the scope of services and depend on services } \\
\text { quality. }\end{array}$ \\
\hline E7 & Stakeholders' satisfaction (e.g. citizens, other organizations, etc.). \\
\hline
\end{tabular}

The results show that the possibilities of an individual to access infrastructure for the basic needs for living (including to rent or to own an apartment), healthcare and education correlate with the capability of the organization to:

- $\quad$ adjust the number of employees,

- $\quad$ adjust the content and organization of the work by using different types of employment and overworking hours

- make flexible types of employment contracts.

The results show that variables of the economic security correlates with variables of the numerical flexibility and variables of the flexible employment contract. Participants who have better possibilities with regards to economic security think that their organization ensures them better possibilities with regards to numerical flexibility and flexible employment contracts.

The results show that the possibilities of the employees to achieve the education, training as well as acquisition, retention and development of their skills and competences are mostly related to adaptation of work to the organizational needs by:

- relocation of employees,

- changing the volume of working hours or timing of work.

Numerical flexibility, functional flexibility and flexibility regarding employment contracts are therefore the most correlated with the basic social security of an individual and the security of reproduction skills. Participants who have better possibilities in the field of numerical and functional flexibility and flexible employment contracts have better possibilities in the context of economic security and security of the reproduction skills (e. g. education, training).

The result of the research show that the capability to wages adjusts is the most associated with:

- the opportunities of employees to obtain the means of subsistence,

- $\quad$ the opportunities for wage adjustment.
Wage flexibility is therefore the most strongly related to income and social security of individuals. This result is logical: participants who have better wages have better possibilities in the field of economic security.

The results show that correlation between all groups of flexibility and security variables in the field of work exists; therefore, Hypothesis H1:

The correlation between different types of flexibility and security in the field of work exists is confirmed. Arguments are taken at relatively low level of the risk $(\alpha=$ $0.001)$.

The results of the research show that there is a medium positive correlation between group of the security variables and organizational efficiency variables. The correlation does not exist between only one group of variables (F5), which represents variable of capability of an organization to adjust wages upon the job performers of each employee, results and their business performers. The correlation also does not exist for the group of variables of organizational efficiency (U6), which includes achievements of the short-term operational goals in terms of volume and quality of services. With the exceptional of the three arguments, which are marked in bold in Table 6 , all other arguments are taken at relatively low level of the risk ( $\alpha$ $=0.001)$.

All the groups of security variables are the best related with the evaluated group of the compliance of services/ products to the standards of quality of services/products. The results show that the quality standards of the products or services that organization depends on the possibilities of an individual:

- to access infrastructure for basic health needs (in general and workplace),

- to have opportunities for wage coordination,

- for protection from large changes in working conditions (by the current employer),

- to have working conditions in the organization 
Table 6: Pearson correlation coefficients $(n=835)$. Source $=$ own

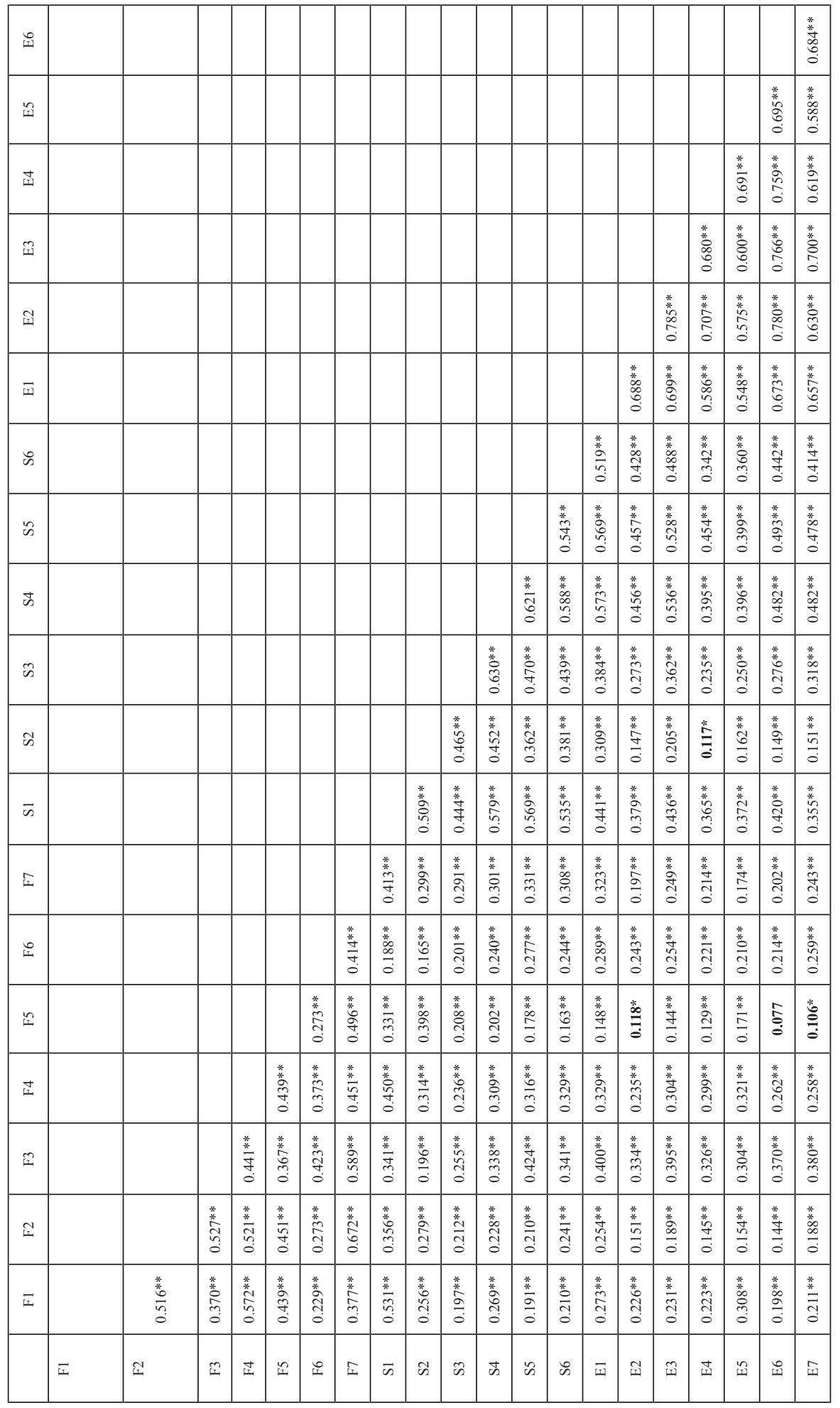

Legend: $* * \ldots . . \mathrm{p}<0.001$

*...... p $<0.005$ 
that are safe and provide well-being,

- to achieve education and training and opportunities for skills and competences acquisition, retention and development,

- to a work-life balance.

Therefore, organizations need to be aware that if their employees have good opportunities with regard to economic, income, workplace, work and combination security, their products or services will have better quality.

The results of the research show medium strong positive correlation between the variables of security and organizational efficiency; therefore, Hypothesis H2:

The correlation between different types of security in the field of work and organizational efficiency exists is confirmed.

The results of the research show that the organizational cost efficiency is the most related to the wage and external numerical flexibility. The quality of services/products is most related to:

- $\quad$ adjustment to work for the needs of the organization by using different forms of employment, by using overtime, copyrights and by changing volume of working hours or the timing of work,

- adjustment of the content of work to the needs or the organization,

- relocation of employees,

- $\quad$ establishment of flexible types of employment contracts.

Internal numerical flexibility, functional flexibility and other flexible types of employment contracts are thus the most related to the quality of services/products. Therefore, organizations need to be aware that products or services will have better quality if their employees will have good opportunities with regard to numerical and functional flexibility and flexible employment contracts.

Results of the research show low positive levels of correlation between all types of flexibility in the field of work and organizational efficiency (Pearson coefficients are lower than 0.5 ). Variables of the flexibility do not correlate with the ability of organization to adjust wages and with achieving short-term goals with regard to the volume and quality of services/products $\alpha>0.005(\alpha=0.028)$. Therefore, Hypothesis H3:

The correlation between different types of flexibility in the field of work and organizational efficiency exists is confirmed.

\section{Discussion}

The results of the research regarding flexibility variables show that employees in the private sector evaluated most flexibility variables more highly than employees in the public sector did. Participants in the research from the private sector have better possibilities with regard to numerical and functional flexibility and mobility. Participants from the public sector in general evaluated the situation in the field of work flexibility as being low. They evaluated the possibilities for tele-working worse than those from the private sector. Changes regarding increasing flexibility that would enable tele-working need to be performed by changing the relevant labour legislation.

Participants from the private and public sectors both agree that organizations do not hire employees through employment agencies very often. The reason might be the lack of trust or previous bad experience that some individuals had in the past. This can be avoided by supervising these employment agencies more closely.

The results of the research show that participants from the private sector organizations evaluated most security variables higher than those from the private sector did. Participants from both sectors evaluated security in the area of infrastructure for basic healthcare as the highest. That is understandable because labour legislation in Slovenia requires employers to register workers with the social insurance system and with the unemployment insurance system.

The possibilities of an individual to buy or rent an apartment or house are the lowest evaluated variables. This result might be a consequence of the current situation at the labour market, which is a result of the recent economic recession and the fact that, during this period, unemployment has risen only among the employees in the private sector. The state has to do more in the field of housing market, in order to increase the possibilities of individuals buying or renting an apartment or house.

Participants from the private sector organizations evaluated most of the variables of the organizational efficiency more highly than public sector participants did. The economic recession, as well as the planned reduction of employment in the public sector, might have an impact on the result.

The comparison between participants employed on managerial workplaces and those on non-managerial workplaces shows that the former have better opportunities with regard to functional flexibility, which is often also associated with better opportunities for participating in education and training, which also affects better payment.

The results of the research show that participants employed on managerial workplaces have better opportunities with regards to economic security, workplace security, job skills security and combination security. That might be because participants from the non-managerial workplaces evaluated these variables rigorously. Nevertheless, participants employed on managerial and non-managerial workplaces should have the same opportunities. Organiza- 
tions need to pay more attention to education. Greater educational opportunities for employees in managerial work places also mean better conditions with regard to functional and wage flexibility.

The results for the organizational efficiency variables show that participants employed on both managerial and non-managerial workplaces evaluated these variables as good. The process of information for the participants employed on the non-managerial workplaces should be more transparent. The results show that those participants evaluated quality standards and the quality of service provision and stakeholder's satisfaction as worse, which might be because they evaluated these variables more rigorously.

The results show that correlations between all groups of flexibility and security variables in the field of work exist. The variables of economic security correlate with the variables of numerical flexibility and the variables of flexible employment contracts. Participants who have better possibilities with regard to economic security think that their organization provides better possibilities with regard to numerical flexibility and flexible employment contracts. Numerical flexibility, functional flexibility and flexibility regarding employment contracts are therefore the most correlated with basic social security of an individual and the security of reproduction skills. Participants who have better possibilities with regard to numerical and functional flexibility and flexible employment contracts have better possibilities with regard to economic security and security of the reproduction skills (e.g. education, training). Wage flexibility is the most related to income and social security of individuals. This is logical, since participants who have better wages have better possibilities for economic security.

The correlation between flexibility of organization and security of an individual has been studied by other authors. Muffels and Luijkx (2005) state that other organizations that are able to compete on the labour market successfully are also able to afford higher levels of social security, which is also a requirement for maintaining high levels of flexibility. Elmeskov et al. (1998), Cazes and Nesporova (2001) OECD (1999; 2004), Kahn (2005), and the European Commission (2006) link strict employment protection legislation to:

- the unemployment of the young people, people who are less skilled, older and female,

- $\quad$ increasing atypical forms of employment during times of economic growth,

- the possibility of the allocation of employees to other (worse) job positions within organizations,

- structural dynamics,

- more frequent temporary employment contracts,

- the duration of employment with the same employer,

- $\quad$ increasing the percentage of self-employed (in total employment).
The results of the research show a medium strong positive correlation between the variables of security and organizational efficiency. All groups of the security variables are most related with the evaluated group of the compliance of services/products to the standards of quality of services/ products. Therefore, organizations need to be aware that if their employees have good opportunities for economic, income, workplace, work and combination security, their products or services will have better quality. Internal numerical flexibility, functional flexibility and other flexible types of employment contracts are therefore the most related to the quality of services/products. Therefore, organizations need to be aware that products or services will have better quality if their employees will have good opportunities for numerical and functional flexibility and flexible employment contracts.

Regarding the correlation between the variables of security and organizational efficiency, authors have different opinions. Wright and Davis (2003) state that higher security of employment has an impact on lower motivation for work and lower productivity. Dessler (1993), Guest (2004), Egger-Peitler et al. (2007), Wanyama and Mutsotso (2010), Talebi et al. (2012) state that security of employment has a positive impact on independency, motivation, productivity of the employees and increase their loyalty to the organization; salaries, employment security, security and health at work, possibilities regarding education and promotion have also an impact on the efficiency of the organizations. Baptiste (2008) and Regus Global Report (2011) and Kozjek et al. (2014) state that easier harmonization of professional and family (private) life leads to lower employee absence, their greater accuracy in the work, higher productivity and loyalty to the organization.

Helpern (2005), Kossek (2005), Rowlattova et al. (2006), Davis and Kalleberg (2006), Kelly et al. (2008), Kossek and Hammer (2008), Kossek and Michel (2010) studied flexibility in relation to the organizational efficiency. They determined that a correlation between flexibility and organizational efficiency exists. Flexibility in the organization has a positive effect on the efficiency.

The link to the online questionnaire was sent by e-mail to official e-mail addresses, asking them to forward it to employees. We do not know whether this was done. This could imply that the research did not include manual workers, industry workers but mainly workers in administration; or that questionnaire completed by one or many employees from the same organization. The reason of low responsiveness rate was that the survey was carried out online. Other reasons that employee state were:

- at the time of our research, they had a number of other research projects in which they participated,

- the leader decided that employees are not allowed to participate in the research,

- $\quad$ they did not have time. 
Conclusions are therefore limited only to the part of the population that has been included in the sample. The research was carried out at the time of the economic crisis, which is also the fact that affect to the results of research. The research should be repeated in times of economic growth and with more participants from private sector organizations.

\section{Conclusion}

Discussions on the perfect balance between flexibility and security in the field of work are more frequent during economic crises. Less attention is given to correlations between flexibility and security in the field of work with the organizational efficiency.

The results of our research show that there is a low positive level of correlation between variables of the flexibility and security in the context of work as well as between variables of the flexibility in the field of work and organizational efficiency. Numerical flexibility, functional flexibility and employment flexibility are the most related to basic social security of an individual and to the security of reproduction skills. Wage flexibility is the most related to income and social security of the individuals. Participants who have better possibilities in the with regard to economic security think that their organization enables better possibilities with regard to numerical flexibility and flexible employment contracts. Participants who have better possibilities with regard to numerical and functional flexibility and flexible employment contracts have better possibilities with regard to economic security and security of the reproduction skills (e.g. education, training).

The flexibility of wages and external numerical flexibility are most related to the cost-efficiency of the organizations. The internal numerical flexibility, functional flexibility and other types of flexible forms of employment contracts are most related to quality of service and products. Therefore, organizations need to be aware that products or services will be of better quality if their employees will have good opportunities with regard to numerical and functional flexibility and flexible employment contracts.

The correlation between variables of the security with regard to work and organizational efficiency is positive and medium strong. Social security, income security, employment security and reproduction and combination security are most related to compliance with the service quality standards. Therefore, organizations need to be aware that if their employees have good opportunities with regard to economic, income, workplace, work and combination security, their products or services will be of better quality.

During the preparation of the legislative amendments regarding introduction of flexibility and security in the field of work, it is therefore necessary to realize the importance of their correlation with organizational efficiency.
The fact that efficiency of organizations is more related to the security of individuals, rather than flexibility of organizations must not be forgotten. There must be good reasons to increase the flexibility in the field of work; otherwise, a lower level of efficiency of organizations can be expected.

\section{References}

Altuzarra, A., \& Serrano, F. (2010). Firms' Innovation Activity and Numerical Flexibility. ILRReview, 63(2), 327-339.

Aristovnik, A., et al. (2012). Vzpostavitev sistema merjenja učinkovitosti, uspešnosti in kakovosti v slovenski policiji. Ciljno raziskovalni projekt. Končno poročilo raziskave. [Establishment of the system for the efficiency, effectiveness and quality measurement, in the Slovenian police. Targeted Research Project. Final report of the research]. Retrived 05. 12. 2012 from http:// www.mnz.gov.si/fileadmin/mnz.gov.si/pageuploads/ SOJ/word/Tacen_15112012/CRP_koncno_porocilo V5-1037_.pdf

Baptiste, N., R. (2008). Tightening the link between employee wellbeing at work and performance. A new dimension for HRM. Management Decision. 46(2), 284309, http://dx.doi.org/10.1108/00251740810854168

Cazes, S., \& Nesporova, A. (2001). Towards Excessive Job Insecurity in Transition Economies. Employment Papers. Employment sector. Genova: International Labour Office.

Davis, A., \& Kalleberg, A. (2006). Family friendly organizations: Work and family programms in the 1990. Work and Occupations, 33(2), 191-223, http://dx.doi. org/10.1177/0730888405280446

Dessler, G. (1993). Winning Commitment. New York: McGraw Hill.

Egger-Peitler, I., Hammerschmidt, G., \& Meyer, R., E., (2007). Motivation, Identification and Incentive Preferences as Issues for Modernisation and HR Strategies in Local government. First Evidence from Austria. The proposed paper forms part of a research project 'Public Service Motivation Characteristics of motivation in public administration and opportunities for improving incentives in public management', Funded by the 'Jubiläumsfonds der Stadt Wien'. Retrieved 15. 12. 2014 from https://soc.kuleuven.be/io/egpa/HRM/madrid/ EggerPeitler-Hammerschmid\&Meyer2007.pdf

Eichorst, W., Feil, M., \& Marx, P. (2010). Crisis, What Crisis? Patterns of Adaptation in European Labour Markets. IZA Discussion paper no. 5045. Retrieved 29. 11. 2012 from http://ftp.iza.org/dp5045.pdf

EIPA (2013). The Common Assessment Framework (CAF). Improving Public Organisations through Self-Assessment. CAF 2013. Retrieved 05. 12. 2012 from http://www.eipa.eu/files/File/CAF/CAF_2013. pdf 
Elmeskov, J., Martin, J. P., \& Scarpetta, S. (1998). Key Lessons for Labour Market Reforms: Evidence from OECD Experience. Swedish economic Policy Review, 2(5), 205-252.

European Comission, (2006). Employment in Europe 2006. Directorate-General for Employment, Social Affairs and Equal Opportunities. European Commission, Luxembourg. Retrieved 17. 01. 2009 from http://digitalcommons.ilr.cornell.edu/cgi/viewcontent.cgi?article $=1031 \&$ context $=$ intl

European Commission (2009). Geographical and labour market Mobility. Report. Special Eurobarometer 337. Retrieved 04. 11. 2011 from http://ec.europa.eu/public_opinion/archives/ebs/ebs_337_en.pdf

Goodwin, A. (2002). EMU Market Dynamics: Labour Market Flexibility in Europe. CBI Organisation, Great Britain.

Green, C. P. \& Leeves, G. D. (2013). Job security, financial security and working well-being: New evidence on the effects of flexible employment. Scottish Journal of Political Economy, 60(2), 121-138.

Guest, D. (2004). Flexible employment contract, the psychological contract and employee outcomes: an analysis and review of the evidence. International Journal of Management Reviews, 5/6(1), 1-19, http://dx.doi. org/10.1111/j.1460-8545.2004.00094.x

Halpern, D. F. (2005). How time-flexible work policies can reduce stress, improve health and save money. Stress and Health. 21, 157-168, http://dx.doi.org/10.1002/ smi.1049

Herzog-Stein, A. \& Zapf, I. (2014). Navigating the great recession: The impact of working-time accounts in Germany. Industrial \& Labor Relations Review, 67(3), 891925, http://dx.doi.org/10.1177/0019793914537455

Hobson, B. (2014). Introduction: capabilities and agency for work-life balance - a multidimensional framework. In: Hobson (ed). Worklife balance. The Agency \& Capabilities Gap. United Kingdom: Oxford University Press, pp. 1-31.

ILO (2004). Economic security for a better world, Genova.

ILO (2004a). Making work arrangements more family-friendly, Genova.

Jonsson, D. (2007). Flexibility, stability and related concepts. In Furĺker, B., Híkansson, K. \& Karlsson, J. (Eds.), Flexibility and stability in working life (pp. 30-41). Hampshire: Palgrave Macmillan.

Kahn, L., M. (2005). The impact of employment protection mandates on demographic temporary employment patterns: international Microeconomic evidence. IZZA Discussion Paper, no. 1548. Retrieved 14. 03. 2009 from http://ftp.iza.org/dp1548.pdf

Kelly, E., Kossek, E., Hammer, L., Durham, M., Bray, J., Chermack, K., Murphy, L., \& Kaskubar, D. (2008). Getting There From Here: Research on the Effects of Work-Family Initiatives on Work-Fami- ly Conflict and Business Outcomes. The Academy of Management Annals, 2(1), 305-349, http://dx.doi. org/10.1080/19416520802211610

Koh, S., C., Saad, L., S., M. (2007). Benchmarking the management of operations and informations systems. New York: Emerald Group Publishing.

Kossek, E., E. (2005). Workplace policies and practices to support work and families. In: Bianchi, S., Casper, L., King, R., (ed.). Work, Family, Health and Well-Being. Elrbaum Press: 97 - 116.

Kossek, E., Hammer, L. (2008). Work/Life Training for supervisors gets big results. Harward Business Review, November.

Kossek, E., E., \& Michel, J., S. (2010). Flexible work schedules. In: Zedeck, S. (ed). APA Handbook of industrial and organizational psychology. American Psychological Association, Washington DC.

Kovač, P. (2007). Podjetniški koncepti kot gibalo modernizacije slovenske javne uprave. [Business concepts as the driver of the modernization of Slovenian public administration]. In: Ferfila, B. et al. Ekonomski vidiki javnega sektorja, University of Ljubljana, Faculty of Social Sciences, 94-265.

Mandl, U., Dierx, A., \& Ilkovitz, F. (2008). European Economy. The effectiveness and efficiency of public spending. Economic and Financial Affairs, European Commission, Economic Papers 301. Retrieved 14. 01. 2011 from http://ec.europa.eu/economy_finance/publications/publication11902_en.pdf

Kozjek, T., Tomaževič, N., \& Stare, J. (2014). Work-life balance by area, actual situation and expectations - the overlapping opinions of employers and employees in Slovenia. Organizacija, 47(1), 35-51, http://dx.doi. org/10.2478/orga-2014-0004

Muffels, R., \& Luijkx, R. (2005). Job Mobility and Employment Patterns Across European Welfare States. Is there a "Trade off" or a "Double Bind" Between Flexibility and Security. Institute for Labour Studies, Amsterdam. Retrieved 25. 05. 2010 from http://www. siswo.uva.nl/tlm/root_files/WorkP05-12MuffLuyk.pdf

Nesadurai, H. E. S. (2005.) Conceptualising Economic Security in an Era of Globalisation: What does the East Asian Experience Reveal? CSGR Working Paper, No. $157 / 05$, Centre for the Study of Globalisation and Regionalisation (CSGR), University of Warwick, United Kingdom. Retrieved 15. 12. 2014 from http://wrap. warwick.ac.uk/1963/1/WRAP_Nesadurai_wp15705. pdf

OECD (1999). Employment Protection and Labour Market Performance. Employment Otlook 1999, Paris. Retrieved 24. 03. 2010 from http://www.oecd.org/els/ employmentpoliciesanddata/2079974.pdf

OECD, (2004). OECD Employment Outlook 2004, Paris. Retrieved 24. 03. 2010 from http://www.oecd.org/employment/employmentpoliciesanddata/32494755.pdf 
Pitt-Catsouphes, M., Matz-Costa, C., \& Bessen, E. (2009). Workplace flexibility: Findings from the Age \& Generation Study. Issue Brief 19. The Sloan Center on aging and work by Boston College. Retrieved 29. 11. 2012 from http://www.bc.edu/content/dam/files/research sites/agingandwork/pdf/publications/IB19_WorkFlex. pdf

Richman, A., Burrus, D., Buxbaum, L., Shannon, L., \& Yai, Y. (2010). Innovative Workplace Flexibility Options for Hourly Workers. Corporate Voices for Working Families. Retrieved 29. 11. 2012 from http://www. cvworkingfamilies.org/system/files/CVWFflexreport-FINAL.pdf

Robbins, S., P., \& Coulter, M. (2005). Management. Pearson Prentice Hall, New Jersey.

Rolstadas, A. (1995). Enterprise Modelling for Competitive Manufacturing, "Control Engineering Practice". Swedish Standards Institute, 3: 43-50.

Rowlatt, A., et al. (2006). Flexible Working: working for families, working for business. A Report for the Family Friendly Working Hours Taskforce. The Women and Work Commission. 'Shaping a Fairer Future'. Retrieved 10. 12. 2012 from http:/www.dwp.gov.uk/ docs/family-friendly-task-force-report.pdf

Soltwedel, R., Dohse, D., Krieger-Boden, C. (1999). EMU Challenges European Labour Markets. IMF Working Paper, no. WP/99/131, Washington.

Sorber, B. (1999). Performance Measurement in the Central Government Departmens of Netherlands. In: Halachmi A. (ed.) Performance and Quality Measurement in Government. Issues and Experiences, Chatelaine Press: 23-33.

Standing, G. (1999). Global Labour Flexibility. Seeking Distributive Justice. London: Macmillan Press.

State Services Commission (2003). Creating a Positive Work Environment. Respect and Safety in the Public Service Workplace.

Talebi, B., Pakdelbonab, M., Zemestani, G., \& Aghdami, N. (2012). Investigation the Relationship between the Employee's Quality of Work Life (QWL) and Their Effectivness in Banking. European Journal of Experimental Biology, 2(5), 1839-1842.

Tros, F. (2004). Flexicurity and HR Policies for the Older Workers. HSI Working Paper for the Workshop TLM Work Package 7 in Alcala. Retrieved 15. 09. 2011 from: http://www.tilburguniversity.edu/research/institutes-and-research-groups/reflect/publications/papers/ fxp2004_7_tros.pdf
Tros, F., \& Wilthagen, T. (2004). The Concept of »Flexicurity«: a new approach to regulating employment and labour markets in Flexicurity. Conceptual Issues and Political Implementation in Europe. European Review of Labour Research, 10(2), 166-186.

Vermeylen, G., \& Hurley, J. (2007). Varieties of flexicurity: reflections on key elements of flexibility and security. European Foundation for the Improvement of Living and Working conditions, Dublin.

Wachsen, E., \& Blind, K. (2011). More flexibility for more innovation? Working Paper 115, University of Amsterdam. Retrieved 29. 11. 2012 from: http://www. uva-aias.net/uploaded_files/publications/WP115Wachsen,Blind.pdf

Wanyama, K., W., \& Mutsotso, S. N. (2010). Relationship between capacity building and employee productivity on performance of commercial banks in Kenya. African Journal of History and Culture, 2(5), 73-78.

Wilthagen, T., Tros, F., \& Van Lieshort, H. (2004). Towards »Flexicurity«? Balancing Flexibility and Security in EU Member States. European Journal of Social Security, 6(2): 113-136, http://dx.doi.org/10.2139/ ssrn. 1133940

Wright, B., E., \& Davis, B., S. (2003). Job Satisfaction In The Public Sector: The Role of the Work Environment. The American Review of Public Administration, 33(6): 70-90.

Tatjana Kozjek is a Senior Lecturer at the Faculty of Administration, University of Ljubljana, Slovenia. She teaches Theory of Organization, Dealing with People in Public Administration, Organizational Behavior, Basics of Organization, Administrative Operation and Personnel Service. She received her master's degree at the Faculty of Organizational Sciences, University of Maribor and her doctorate at the Faculty of Administration, University of Ljubljana. Her research interests are in flexibility and security in the field of work. She is a member of the Slovenian Human Resource Association and various project groups.

Marko Ferjan is a full professor at the University of Maribor's Faculty of Organizational Sciences. He received his master's degree and doctorate at the University of Maribor. His areas of research include HRM, communication processes in organizations and educational planning. Currently he is a dean of Faculty of Organizational Sciences, University of Maribor. 